\title{
Implementasi Media Visual Dalam Meningkatkan Semangat Belajar Siswa Kelas IV MI Nahdatul Ulama' Ngingas Waru Sidoarjo
}

\author{
${ }^{*}$ Mohammad Roni ${ }^{1}$, Melvy Karenia Putri ${ }^{2},{ }^{*}$ Juhaeni $^{3}$, Ninik Mahyuni ${ }^{4}$, Safaruddin ${ }^{5}$ \\ 1,2,3 Universitas Islam Negeri Sunan Ampel, Surabaya, Indonesia \\ ${ }^{4}$ Madrasah Ibtidaiyah Nahdlatul Ulama Ngingas Waru, Sidoarjo, Indonesia \\ ${ }^{5}$ IAIM Sinjai, Sulawesi Selatan, Indonesia \\ *juhaeni@uinsby.ac.id (Corresponding Author)
}

\begin{tabular}{l}
\hline A) Check for updates \\
\hline Informasi Artikel \\
\hline Riwayat Artikel: \\
Diterima: 20 Oktober 2021 \\
Revisi Akhir: 25 November 2021 \\
Disetujui: 05 Desember 2021 \\
Terbit: 31 Desember 2021 \\
\hline Kata Kunci: \\
Media Visual \\
Semangat \\
Siswa
\end{tabular}

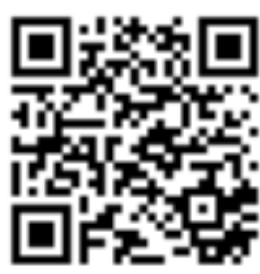

DOI: https://doi.org/10.53621/jider.v1i3.73

\section{PENDAHULUAN}

Pada hakikatnya pendidikan adalah sebuah usaha yang dilakukan sebagai bentuk memanusiakan manusia dengan potensi yang dimiliki dan juga menyesuaikan kebutuhan lingkungan sekitarnya. Dengan pendidikan manusia dapat mempertahakan hidupnya dari generasi ke generasi sesuai dengan perkembangan peradaban. Pendidikan juga diartikan sebagai bantuan atau usaha yang dilakukan oleh orang dewasa kepada anak sebagai bentuk pendewasaan diri untuk menyelasaikan tugas kehidupannya sehari-hari (Hasbullah, 2013).

Banyak cara yang dapat dilakukan untuk membangun pendidikan kedalam jiwa manusia, salah satunya yaitu dengan memberikan semangat belajar. Belajar merupakan proses penting yang ada dalam kehidupan masyarakat. Setiap manusia pasti mengalami proses belajar dalam kehidupannya. Dalam perjalanan hidup manusia, belajar terjadi saat sejak lahir sampai menjadi mati. Proses belajar dalam hidup manusia terjadi karena adanya intreaksi antara manusia tersebut dengan lingkungan sekitarnya. Proses belajar juga bisa terjadi kapanpun dan dimanapun baik disekolah ataupun dirumah (Musfiqon, 2012).

Sekolah merupakan tempat yang selama ini digunakan sebagai tempat berlangsungnya proses belajar mengajar. didalam lingkungan sekolah terdapat beberapa unsur yang berperan dalam proses belajar mengangajar diantaranya adalah guru. Guru adalah seorang yang berperan penting dalan sebuah proses pembelajaran 
hal ini dikarenakan guru adalah fasilitator sekaligus pengelola dalam proses pembelajaran. Oleh karena itu seorang guru harus mempersiapkan dirinya sebelum mengajar agar materi yang disamapaikan dapat mudah difahami oleh siswa. (Pidarta, 2009).

Untuk menjadi seorang guru professional dan bertanggung jawab maka seorang guru harus dapat meningkatkan kualitas mengajarnya, salah satu upaya yang dapat dilakukan untuk meningkatkan kuaitas pendidikan yaitu dengan cara mengunakan media secara efektif dalam setiap proses pembelajaran sehingga dengan menggunaka media tersebut proses pembelajaran menjadi lebih berkualitas dan siswa dapat menerima materi dengan baik (Sanaky, 2009).

Penggunanaan media dirasa penting dalam proses pembelajaran sebab tanpa adanya media siswa tidak begitu tertarik dengan proses pembelajaran yang berlangsung. Maka guru harus bisa memilih media yang tepat untuk digunakan dalam setiap pembelaaran agar siswa dapat mengikuti pembelaaran dengan penuh semangat. Media juga diartikan sebagai alat yang dapat merangsang pikiran dan juga keterampilan serta kemampuan siswa sehingga terjadi proses pembelajaran yang aktif dan siswa bersemangat dalam mengikuti proses pembelajaran. Media juga bisa dijadikan sebagai alat yang membantu proses pembelajaran. Sehingga guru yang telah memilih media dengan tepat dan sesuia dengan materi serta prosedur yang ada diaharapkan siswa dapat menerima materi yang diaarkan oleh guru secara sempurna (Subini, 2012).

Terdapat banyak media yang dapat digunakan dalam proses pembelajaran salah satunya yaitu media visual. Media visual yaitu media yang hanya mengandalkan indra pengliat (Djamarah, 2010). Terdapat banyak macam media visual diantaranya foto, lukisan gambar, file slide, dan masih banyak lagi. Selain membantu guru dalam menyampaikan materi, media visual juga dapat menjadikan siswa lebih bersemangat dalam mengikuti pembelajaran hal ini disampaikan oleh Ibu Ninik Wahyuni, S. Ag. Selaku guru kelas IV A MI Nahdlatul Ulama' Ngingas "Memang harus menggunakan media dalam pembelajaran supaya pebelajaran tidak monoton". Beliau juga menambahkan "dengan media visual anak-anak lebih bersemangat dalam mengikuti pembelajaran" berdasarkan uraian tersebut maka peneliti tertarik untuk meniliti tentag implementasi media visual dalam meningkatkan semangat siswa dalam mengikuti pembelajaran dengan judul "Implementasi Media Visual Dalam Menigkatkan Semangat Belajar Siswa Kelas IV A MI Nahdlatul Ulama' Ngingas Waru Sidoarjo".

\section{METODE PENELITIAN}

Penelitian ini menggunakan jenis penelitian kualitaif yaitu penelitian yang ditujukan untuk mengembangkan teori pemahaman serta konsep dilapangan dengan menggunakan deskripsi bahasa yang non numeric dalam konteks serta paradigma ilmiah (Moleong, 2013). Penelitian ini bersifat deskriptif dengan mengambarkan objek penelitian sesuai realitia yang ada (Sukardi, 2003). Subjek penelitian ini adalah siswa kelas IV A MINU Ngingas Waru dan juga dewan guru yang mengajar di kelas IV A. sedangkan objeknya yaitu pengaruh media visual terhadap semangat belajar siswa, Untuk teknik pengumpulan data yaitu menggunakan observasi, wawancara, dan dokumentasi adapun tahapan analisis data dimulai dari (1) reduksi data, (2) Penyajian data, dan (3) penarikan kesimpulan. 


\section{HASIL DAN PEMBAHASAN}

Motivasi belajar berasal dari kata "motif" yang artinya adalah sebagai upaya yang mendorong seseorang untuk melakukan sesuatu (Sadirman \& dkk, 2009). Berawal dari kata motif itu maka motivasi dapat diartikan sebagai daya penggerak yang telah menjadi aktif.

Pendapat Mc. Donald yang dikutip oleh Sadirman mengemukakan bahwa motivasi adalah perubahan energi dalam diri seseorang yang ditandai dengan munculnya feeling. Penelitian ini mendukung tiga elemen penting yaitu:

a. Bahwa motivasi itu mengawali terjadinya perubahan energi pada diri setiap individu manusia

b. Motivasi akan dirangsang karena adanya tujuan

c. Motivasi juga ditandai dengan adanya rasa (Hamalik, 2013)

Motivasi juga bisa dikatakan sebagai serangkaian usaha untuk menyediakan kondisi tertentu. Jadi motivasi tidak hanya dapat merangsang atau dirangsang oleh faktor luar akan tetapi motivasi juga tumbuh dari diri seseorang. Kesungguhan dalam belajar juga perlu adanya motivasi yang sangat kuat karena tanpa motivasi maka hasil belajar yang baik juga kurang bahkan sulit akan tercapai.

Dari beberapa pengertian motivasi yang telah dijabarkan dapat disimpulkan bahwa motivasi adalah sebuah kekuatan atau dorongan mental untuk seseorang. Motivasi juga sangat berperan penting dalam aspek kehidupan seseorang karena dapat menentukan suatu keberhasilan. Menurut Hudoyono mengatakan bahwa cara memberikan motivasi sebagai berikut:
a. Bawalah suasana kelas yang menyenangkan
b. Berikan kepasa siswa kesempatan kompetensi
c. Timbulkan rasa minat belajar siswa terhadap proses pembelajaran
d. Berikan kepada siswa rasa puas sehingga berusaha mencapai keberhasilan
e. Berikan apresiasi
f. Berikan motivasi-motivasi yang menyenangkan
g. Menyeleksi perbuatan
h. Menentukan arah perbuatan kearah tujuan yang dicapai
i. Mendorong manusia untuk berbuat atau melakukan sesuatu (Kusnadi, 2009)

Motivasi belajar adalah keseluruhan daya penggerak didalam diri siswa yang menimbulkan kegiatan belajar dan menjamin kelangsungan dari kegiatan belajar itu. Motivasi belajar penting bagi siswa untuk:
a. Membesarkan rasa semangat pada siswa
b. Mengarahkan kegiatan belajar
c. Menginformasikan tentang kekuatan usaha belajar
d. Menyadarkan kedudukan awal belajar

Motivasi belajar juga merupakan tolak ukur keberhasilan dalam kegiatan pembelajaran. (HAe, 2021). Apabila siswa memiliki motivasi tinggi dalam pembelajaran maka kegiatan pembelajaran akan menadi menarik dan siswa antusias dalam mengikuti setiap pembelajaran. Hal ini senada dengan pendapat Bapak Surano sebagai guru PJOK kelas IV A yang menyatakan bahwa "keberhasilan pembelajaran akan mudah tercapai jika siswanya memiliki semangat yang tinggi.

Dalam proses pembelajaran penerapan media mempunyai peranan yang sangat penting untuk meningkatkan semanagat belajar siswa. Media dapat membantu guru apabila terdapat materi yang belum tersamapaikan secara lisan sehingga proses pembelajaran tetap berjalan dengan efektif. Media juga sebagai perantara untuk 
membantu siswa agar lebih mudah memahami materi yang disampaikan oleh guru (Damarah, 2006). Hal ini juga sesuai dengan pendapat yang diungkapkan Ibu Sekar bahwa " media dapat membantu siswa dalam menerima materi.

Media pembelajaran adalah media yang digunakan untuk membangun merangsang pikiran, perasaan, kemampuan dan perhatian siswa dalam proses belajar mengajar di kelas. Media tersebut berupa alat ataupun bahan mengajar. Menurut Nana Sudjana dan Ahmad Rivai mengatakan media pembelajaran bisa memperkuat proses belajar mengajar siswa didalam pengajaran yang kemudian mampu mempertinggi pengaruh belajar yang diraih siswa (Rivai, 2015). Selain itu media memiliki bermanfaat beberapa manfaat, yaitu:

a. Pesan atau materi yang disampaikan lebih jelas dan tidak terlalu bersifat verbalitas.

b. Mengantisipasi tebatasnya, waktu, ruang, tenaga, serta daya indra.

c. Merangsang semangat belajar, siswa berinteraksi langsung dengan media pembelajaran.

d. Menjadikan siswa mandiri dalam belaar sesuai dengan kemampuannya.

e. Menselerasikan rangsangan terhadap pengalaman, serta menumbuhkan persepsi baru.

f. Kegiatan pembelajaran terdiri dari lima unsur komunikasi yaitu: (Budiman, 2016)

1. Guru (komunikator)

2. Bahan ajar

3. Media pembelajaran

4. Siswa (komunikan)

5. Tujuan pembelajaran

Selanjutnya Sadirman Arief mengemukaan bahwa media juga memiliki manfaatnya itu:

a. Penyampaian materi pembelajaran dapat diregamkan

b. Proses pembelajaran menjadi lebih jelas dan menarik

c. Proses pembelajaran menjadi interaktiv

d. Meningkatkan kualitas hasil belajar siswa

e. Dapat dilakukan dimana saja

f. Menumbuhkan sikap positif siswa untuk belajar

g. Merubah pesan guru kearah yang lebih positiv

Menurut penjelasan di atas bisa disimpulkan bahwa media pembelajaran adalah media komunikasi, menyalurkan pesan atau informasi dari guru kepada siswa, mendukung metode pembelajaran yang digunakan menjadi satu alat bantu.

Media visual adalah sebuah penyajian materi ajar dengan menggunakan bahan ajar yang dapat memperagakannya sehingga siswa dapat melihat, merasakan, seta mengamatai secara langsung bahan bahan ajar yang digunakan (Maroa, n.d.). Penerapan media visual juga berpengaruh terhadap perkembangan siswa. hal ini ditinjau dari bagaimana antusias siswa ketika guru menyampaikan materi dengan menggunakan media visual, siswa yang mulanya pasif akan menjadi aktif mengikuti kegiatan pembelajaran. Antusiasme siswa dalam mengikuti pembelajaran menandakan bahwa siswa bersemangat dalam mengikuti sebuah kegiatan pembelajaran (Rojanah, 2021). Dalam penerapannya terdapat beberapa jenis media visual yang dapat diterapkan dalam setiap kegiatan pembelajaran, seperti:
a. Gambar atau Foto
b. Chart atau Bagan 
c. Grafik

d. Peta dan Globe (Muntahanah, 2014)

Penelitian ini bertujuan untuk mengatahui implementasi media visual dalam meningkatkan semangat belajar siswa kelas IV di MINU NGINGAS tahun ajaran 2021/2022. Berdasarkan data penelitian yang telah dianalisis, ringkasan hasil penelitian dapat dilihat pada hasil wawancara dari guru wali kelas IV yang telah diwawancarai. Menurut Ibu Ninik selaku wali kelas IV A mengatakan bahwa “ penggunaan media visual dapat merangsang semangat belajar siswa serta dapat mempermudah siswa dalam mencerna materi yang disampaikan oleh guru".

Selain itu Ibu Sekar sebagai salah satu pengajar di kelas IV A mengungkapkan "Media digunakan saat menyampaikan materi serta terdapat perbedaan saat tidak menggunakan media anak-anak bosan untuk menerima pembelajaran, sehingga kadang tidak memperhatikan, tetapi jika memakai media dan ada perhatian untuk menerima materi". Pengunaan media visual dapat meningkatkan semangat belajar siswa karena penggunaan media visual anak dapat melihat secara langsung. penggunaan media visual dapat menarik minat dan belajar siswa karena siswa lebih focus memperhatikan suatu materi yang diberikan oleh guru kelas. Bisa kita lihat pendapat para guru kelas IV bahwasannya penggunaan media visual dalam pembelajaran itu sangat menarik perhatian, memperjelas sajian dan dapat dicerna dengan baik oleh siswa, akan tetapi "jika terlalu lama mereka juga bosan, sehingga kadang saya kolaborasi dengan metode lain, misal quick on the draw, inquiry, dan lainlain" ujar bu sekar selaku wali kelas 4B. pembelajaran dengan media visual dengan syarat, video tidak terlalu lama, dan menarik untuk dilihat.

Dengan demikian hasil penelitian ini membuktikan bahwa media visual memberikan pengaruh yang sangat besar terhadap hasil belajar siswa. Motivasi belajar siswa selama kegiatan belajar mengajar dengan penerapan media berbasis visual terjadi peningkatan secara positif (Dkk, 2014). Dengan digunakannya media pembelajaran, peserta didik meningkatkan prestasi belajar juga. Siswa dapat mengembangkan keaktifannya didalam kelas dikarenakan penggunaan media pembelajaran dapat menumbuhkan motivasi belajar siswa sehingga meningkatkan semangat belajar siswa sehingga meningkatkan hasil belajar karena siswa semangat belajar. Tentu saja dalam hal ini hasil belajar siswa meningkat dan siswa tidak cepat bosan dalam proses pembelajaran. Hal ini dapat dilihat dari pembelajaran lebih banyak menekankan siswa aktif di dalam kelompoknya sedangkan guru hanya bertugas sebagai fasilitator dan motivator dalam pembelajaran.

\section{KESIMPULAN DAN SARAN}

Berdasarkan Berdasarkan hasil penelitian dan pembahasan di atas, dapat disimpulkan bahwa terdapat perbedaan yang signifikan terhadap hasil belajar siswa yang mengikuti pembelajaran dengan bantuan media visual dan tidak menggunakan media. Adanya perbedaan yang signifikan menunjukkan bahwa pembelajaran berbantuan media visual berpengaruh positif terhadap hasil belajar siswa kelas IV.

Saran yang dapat disampaikan berdasarkan penelitian yang telah dilakukan adalah sebagai berikut. Kepada Guru Hendaknya dalam pelaksanaan proses pembelajaran agar menerapkan model pembelajaran dengan bantuan media visual atau model pembelajaran yang lain yang didukung dengan teknik belajar yang relevan, sehingga hasil belajar siswa semakin meningkat. 


\section{UCAPAN TERIMA KASIH}

Atas selesainya penulisan hasil penelitian ini, peneliti mengucapkan terima kasih kepada Bapak dan Ibu guru di MINU Ngingas Waru terkhusus Ibu Kepala Madarasah karena telah berkenan memberikan izin, dan telah berpartisipasi dalam bentuk waktu dan tenaganya dalam proses penelitian dan penulisan hasil penelitian ini. Kedua kalinya, tak lupa peneliti ucapkan terima kasih kepada Ibu Juhaeni, M.Pd.I selaku Dosen Pembimbing yang senantiasa meluangakn waktu dan tenaganya dalam membimbing peneliti dalam menyelesaikan penelitian ini.

\section{DAFTAR PUSTAKA}

Budiman, H. (2016). Penggunaan Media Visual Dalam Proses Pembelajaran. Jurnal Pendidikan Islam, 7.

Damarah, S. B. (2006). Strategi Belajar Mengajar. Rineka Cipta.

Djamarah, S. B. (2010). Strategi Belajar Mengajar. Rineka Cipta.

Dkk, W. (2014). Hubungan Penggunaan Media Pembelajaran dengan Hasil Belajar PKN pada Siswa Kelas X dan XI di SMA Muhammadiyah 1 Banjarmasin. Jurnal Pendidikan Kewarnegaraan, 4(7).

HAe, Y. Y. R. P. T. W. (2021). Penerapan Media Pembelajaran Visual dalam Membangun Motivasi Belajar Siswa Sekolah Dasar. Jurnal Ilmu Pendidikan, 3(4).

Hamalik, O. (2013). Proses Belajar mengajar. Bumi Aksara.

Hasbullah. (2013). Dasar-dasar Pendidikan. PT. Raja Grafindo Persada.

Juhaeni, J., Safaruddin, S., \& Salsabila, Z. P. (2021). Articulate Storyline Sebagai Media Pembelajaran Interaktif Untuk Peserta Didik Madrasah Ibtidaiyah. AULADUNA: $\begin{array}{llll}\text { Jurnal Pendidikan } \quad \text { Dasar } & \text { 150-159. }\end{array}$ https:/ / doi.org/10.24252/AULADUNA.V8I2A3.2021

Juhaeni, S., Nurhayati, R., \& Tanzila, A. N. (2020). Konsep Dasar Media Pembelajaran. JIEES: Journal of Islamic Education at Elementary School, 1 (1), 34-43.

Kusnadi, dkk. (2009). Strategi pembelajaran Inovativ Kontemporer. Bumi Aksara.

Maroa, P. P. C. K. A. H. (n.d.). Penerapan Pembelaaran PKN Dengan Media Visual Untuk Meningkatkan Hasi Belajar Pada Siswa Kelas V SD Inpres 012 Bajawali Kecamatan Lariang Kabupaten Mamuu Utara. Jurnal Kreatif Taduloko Online, 3(3).

Moleong, L. J. (2013). Metodologi Penelitian Kualitati. Edisi Revisi. Cet, 31.

Muntahanah, N. (2014). Penggunaan Media Visual Dalam Pembelajaran PAI. Jurnal Studi Keislaman, 4(1).

Musfiqon. (2012). Pengembangan Media dan Sumber Pembelajar. PT Prestasi Pustaka raya. Pidarta, M. (2009). Landasan Kependidikan. PT. Rineka Cipta.

Rivai, S. (2015). Media Pengajaran Bandung. Sinar Baru Algensindo.

Rojanah. (2021). Penggunaan Media Visual terhadap Motivasi Belajar Siswa pada Mata Pelajaran Fikihdi Madrasah Ibtidaiyah. Journal of Elementary Educational Research, 1(1).

Safaruddin, S., Degeng, I., Setyosari, P., \& Murtadho, N. (2020). The Effect of PjBL with WBL Media and Cognitive Style on Studentsâ€тM Understanding and Science-Integrated Concept Application. Jurnal Pendidikan IPA Indonesia, 9(3), 384-395. doi:https://doi.org/10.15294/jpii.v9i3.24628

Sadirman, A., \& dkk. (2009). Media Pendidikan.

Sanaky. (2009). Media Pembelajaran. Safira Insania Press.

Subini, N. (2012). Mengatasi Kesulitan Belajar. Javalitera.

Sukardi. (2003). Metodologi Penelitian Pendidikan. Bumi Aksara. 